\title{
Effectiveness of Prepared Corn Husk Activated Carbon on the Abatement of Sodium Chloride Content in Fish Sauce
}

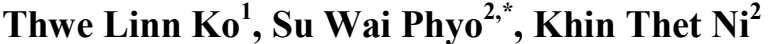 \\ ${ }^{1}$ Industrial Chemistry Department, University of Mandalay, Mandalay, 05032, Myanmar \\ ${ }^{2}$ Industrial Chemistry Department, University of Yangon, Yangon, 11041, Myanmar
}

Copyright $\bigcirc 2018$ by authors, all rights reserved. Authors agree that this article remains permanently open access under the terms of the Creative Commons Attribution License 4.0 International License

\begin{abstract}
Fish sauce is a salt-fermented product that is an economically important fishery product in most Southeast Asian countries. In this study, high sodium chloride content of fish sauce was reduced by environmental friendly adsorbent from agricultural waste (corn husk). The production of activated carbon from agricultural by-product has potential economic and reducing environmental impacts. Corn husk activated carbon was prepared by chemical activation method using zinc chloride $\left(\mathrm{ZnCl}_{2}\right)$ as activating agent. The effect of various preparation parameters such as concentration of activating agent, carbonization temperature and carbonization time that depend on characteristics of activated carbon. Based on the results of the characterization studies, the activated carbon prepared by impregnation the precursor with $20 \% \mathrm{ZnCl}_{2}$, followed by carbonization at $250^{\circ} \mathrm{C}$ for $40 \mathrm{~min}$., was selected as the appropriate condition due to the following good characteristics of activated carbon: high surface area, high iodine sorption capacity, and SEM analysis. In reduction of sodium chloride content in fish sauce, the ratio of 1:50 activated carbon to fish sauce for $120 \mathrm{~min}$. agitation time at $30^{\circ} \mathrm{C}$ was effectively reduced from 31.5 to $26.34(\% \mathrm{w} / \mathrm{w})$. The effective reduction of sodium chloride from commercial fish sauce was significantly observed by processed corn husk activated carbons.
\end{abstract}

Keywords Fish Sauce, Sodium Chloride Content, Activated Carbon, Corn Husk, Chemical Activation, SEM, XRD

\section{Introduction}

Activated carbon, also called activated charcoal, is a form of carbon processed to have small, low-volume pores that increase the surface area available for adsorption or chemical reactions [1]. Activated carbon is perhaps one of the most widely used adsorbents in industry for environmental applications. The utilization of agricultural waste might be the key to a healthy transformation. Converting agricultural waste into activated carbon provides an alternative disposal method, and thus indirectly reduces environmental problems.

Basically there are two different processes for the preparation of activated carbon, the so-called physical or thermal and chemical activation. Chemical activation offers several advantages over physical activation as it is carried out in a single step combination and activation, performed at lower temperatures and therefore resulting in the development of a better porous structure. Moreover, the added chemicals for activation can be easily recovered. Various chemical activating agents such as Trihydrogen phosphate $\left(\mathrm{H}_{3} \mathrm{PO}_{4}\right)$, Potassium hydroxide $(\mathrm{KOH})$ and Zinc chloride $\left(\mathrm{ZnCl}_{2}\right)$ are used in preparation of activated carbon. To easily get rid out of the excess of activating agent, $\mathrm{ZnCl}_{2}$ was used in this study $[2-4,13]$.

Corn, (Zea mays), also called Indian corn or maize, is cereal plant of the grass family (Poaceae). The domesticated crop originated in the Americas and is one of the most widely distributed of the world's food crops [5]. Corn husks are the outer covering of an ear of corn. Corn is widely cultivated in Myanmar and so, corn husk can be used as raw material for the preparation of activated carbon [6].

Fish sauce is widely used as ingredient in curries. Fish sauce is produced by mixing with fish and salt, followed by fermentation. High salt content food is not suitable for human health. In this research, activated carbon was prepared from corn husk by using chemical activation method. The objective of this research work was to prepare environmental friendly adsorbent from agricultural waste, and to reduce the salt content of fish 
sauce by activated carbon prepared at optimum condition.

\section{Materials and Methods}

\subsection{Materials}

Corn husks were collected from Pagoda market, Nan Taw Yar Ward, Bago City, Bago Region, Myanmar. The raw materials were washed gently with water to remove earthy matter and other impurities and then sundried for two-three days. The dried samples were then cut into small pieces (1 inch). Fish sauce (Sein Chae brand, Myanmar) was obtained from Hledan market, Kamayut Township, Yangon Region, Myanmar.

\subsubsection{Preparation of Adsorbent:}

Firstly to determine the effect of concentration of activating agent on physico-chemical properties of activated carbon, dried corn husk was immersed in $\mathrm{ZnCl}_{2}$ solution $(15 \%$ to $30 \%)$ for $24 \mathrm{hr}$. The solution was drained off, and then this husk was dried at $60^{\circ} \mathrm{C}$ for $1 \mathrm{hr}$. This material was put into crucible and the whole set up was placed in a muffle furnace at $200^{\circ} \mathrm{C}$, for $30 \mathrm{~min}$. carbonization time. After cooling, the carbon was repeatedly washed with distilled water to get rid of $\mathrm{ZnCl}_{2}$ and dried at $50^{\circ} \mathrm{C}$ for $30 \mathrm{~min}$.

And then, to investigate the effect of carbonization temperature, corn husks impregnated in optimum concentration of $\mathrm{ZnCl}_{2}$ solution were carbonized at various temperatures $\left(150\right.$ to $\left.350^{\circ} \mathrm{C}\right)$ for 30 min.(carbonization period). The obtained activated carbons were washed and dried repeatedly as mentioned above.

Finally to study the effect of carbonization time on physico-chemical properties of activated carbon, corn husk impregnated in optimum concentration of activating agent followed by carbonizing at optimum temperature were prepared by varying carbonization time from 30 to $50 \mathrm{~min}$.

\subsubsection{Reduction of Sodium Chloride Content in Fish Sauce by Processed Activated Carbon:}

Various ratios of fish sauce to activated carbon were treated by using processed activated carbon at room temperature for $1 \mathrm{hr}$. with stirring $(200 \mathrm{rpm})$. The appropriate ratio of activated carbon to fish sauce was determined and the appropriate temperature and time for the reduction of salt content were also studied.

\subsection{Analytical Methods}

Physico-chemical properties (moisture, ash, volatile matter and fixed carbon content, and bulk density) of raw material and processed activated carbon were investigated. Moisture content of activated carbon and raw material were determined using ASTM D 2867-91 (1991). Bulk density was studied according to the tamping procedure by Ahmedna et al [7]. The volatile matter content was determined by ASTM D 5832-98.

Characteristics of activated carbon such as $\mathrm{pH}$, surface area [8], iodine sorption capacity and methylene blue number [9] were studied. The iodine sorption capacity was determined based on ASTM D 4607-86 (1986). Prepared activated carbon was characterized by using SEM and XRD techniques.

Characteristics of fish sauce ( $\mathrm{pH}$, total nitrogen content, protein content and sodium chloride content) were studied. The $\mathrm{pH}$ of fish sauce was analyzed by AOAC 981.12 (codex general method). Sodium chloride content was measured by Technical Paper 219 AOAC 937.13. Effects of activated carbon to fish sauce ratio, agitation temperature and time on the reduction of sodium chloride content were determined.

\section{Result and Discussion}

\subsection{Physico-chemical Properties of Corn Husk}

Agricultural waste, corn husk is carbonaceous material. The physico-chemical properties of corn husk are shown in Table 1. Fixed carbon content was found to be that of $79.11 \%$.

Table 1. Physico-chemical Properties of Corn Husk

\begin{tabular}{|c|c|}
\hline Properties & Experimental Values \\
\hline Moisture content $(\% \mathrm{w} / \mathrm{w})$ & 6.73 \\
\hline Ash content $(\% \mathrm{w} / \mathrm{w})$ & 1.72 \\
\hline Volatile matter content $(\% \mathrm{w} / \mathrm{w})$ & 4.08 \\
\hline Bulk density $\left(\mathrm{g} / \mathrm{cm}^{3}\right)$ & 0.0348 \\
\hline Fixed carbon content $(\% \mathrm{w} / \mathrm{w})$ & 79.11 \\
\hline
\end{tabular}

3.1.1. Effect of Concentration of Activating Agent on Physico-chemical Properties of Activated Carbon

In studying the effect of concentration of activating agent on physico-chemical properties of activated carbon, $20 \% \mathrm{ZnCl}_{2}$ solution provided the highest fixed carbon content at $200^{\circ} \mathrm{C}$ carbonization temperature and $30 \mathrm{~min}$. carbonization period (Fig.1). The yield of activated carbon increased with increase of concentration of activating agent up to certain value $(25 \% \mathrm{w} / \mathrm{w})$ and then decreased. Increasing concentration of activating agent increases the release of volatiles from the sample and therefore the decrease in yield could be observed.

\subsubsection{Effect of Activating Temperature on} Physico-chemical Properties of Activated Carbon

For activated carbon to have the desired properties, the temperature of carbonization must be well controlled. If the temperature of carbonization is too high, it greatly affects the activity of the activated carbon. In this study, $250^{\circ} \mathrm{C}$ was the optimum carbonization temperature for preparation of activated carbon in $20 \% \mathrm{ZnCl}_{2}$ solution for $30 \mathrm{~min}$. due to maximum fixed carbon content with minimum ash content (Fig. 2). 


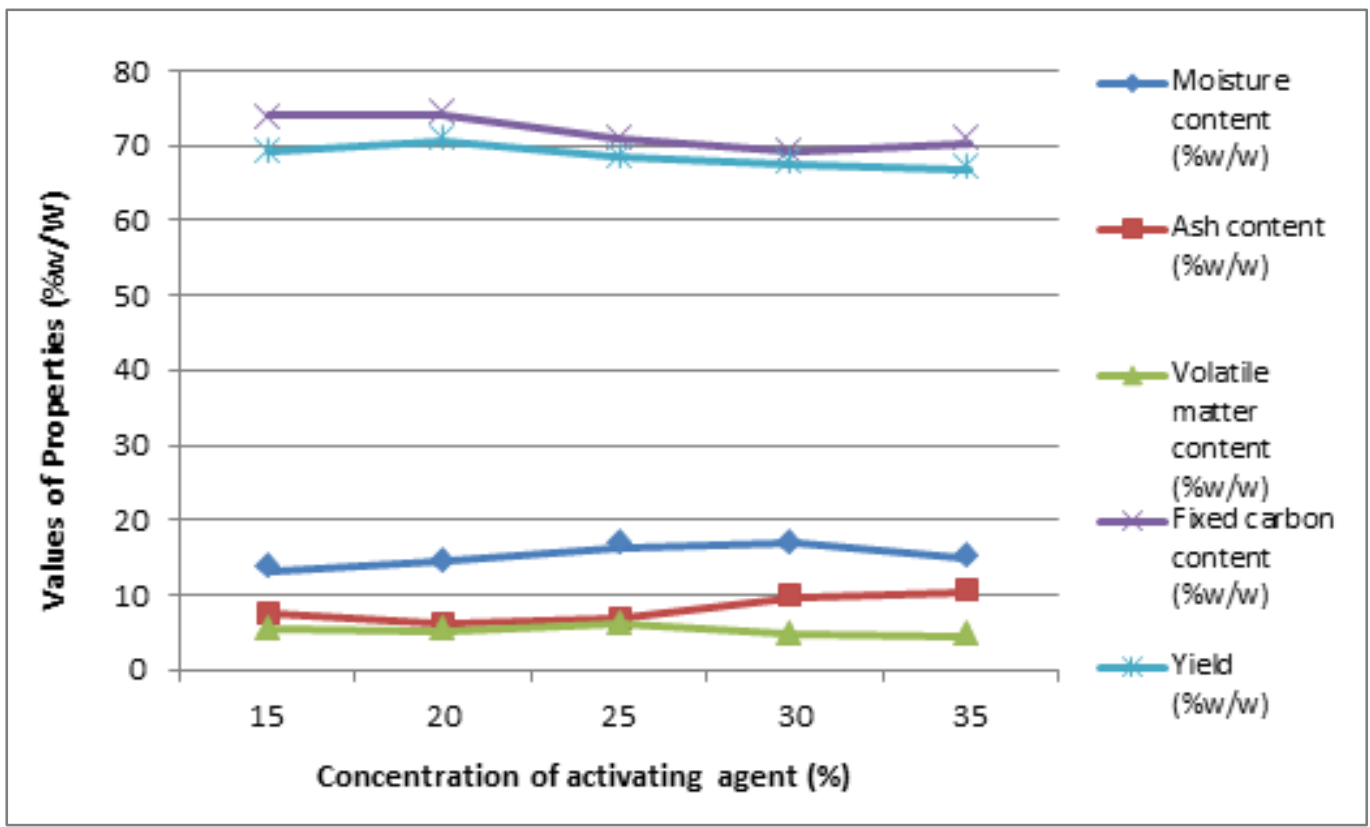

Figure 1. Effect of Concentration of $\mathrm{ZnCl}_{2}$ on the Physico-chemical Properties of Corn Husk Activated Carbon

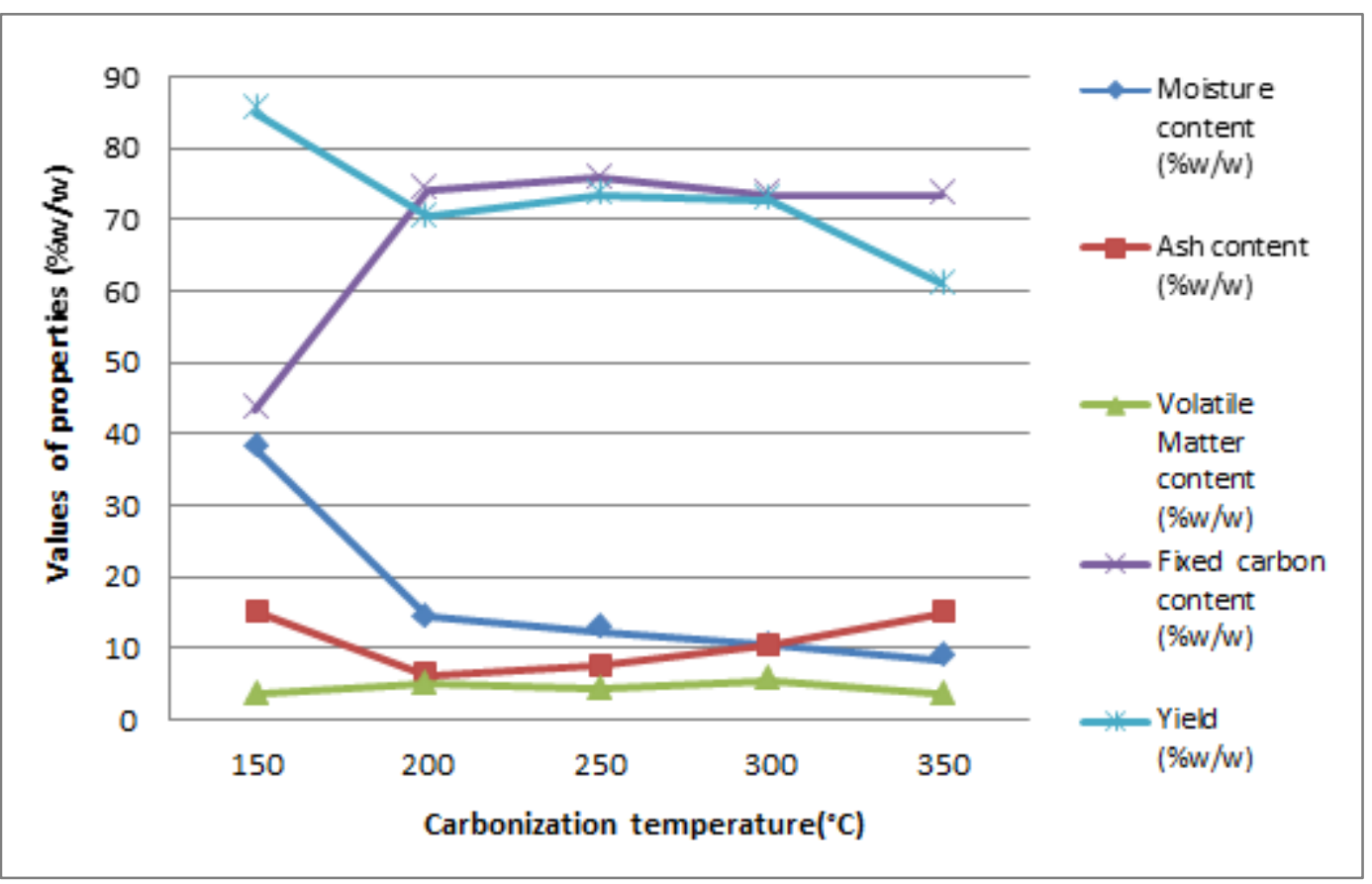

Figure 2. Effect of Carbonization Temperature on the Physico-chemical Properties of Corn Husk Activated Carbon 


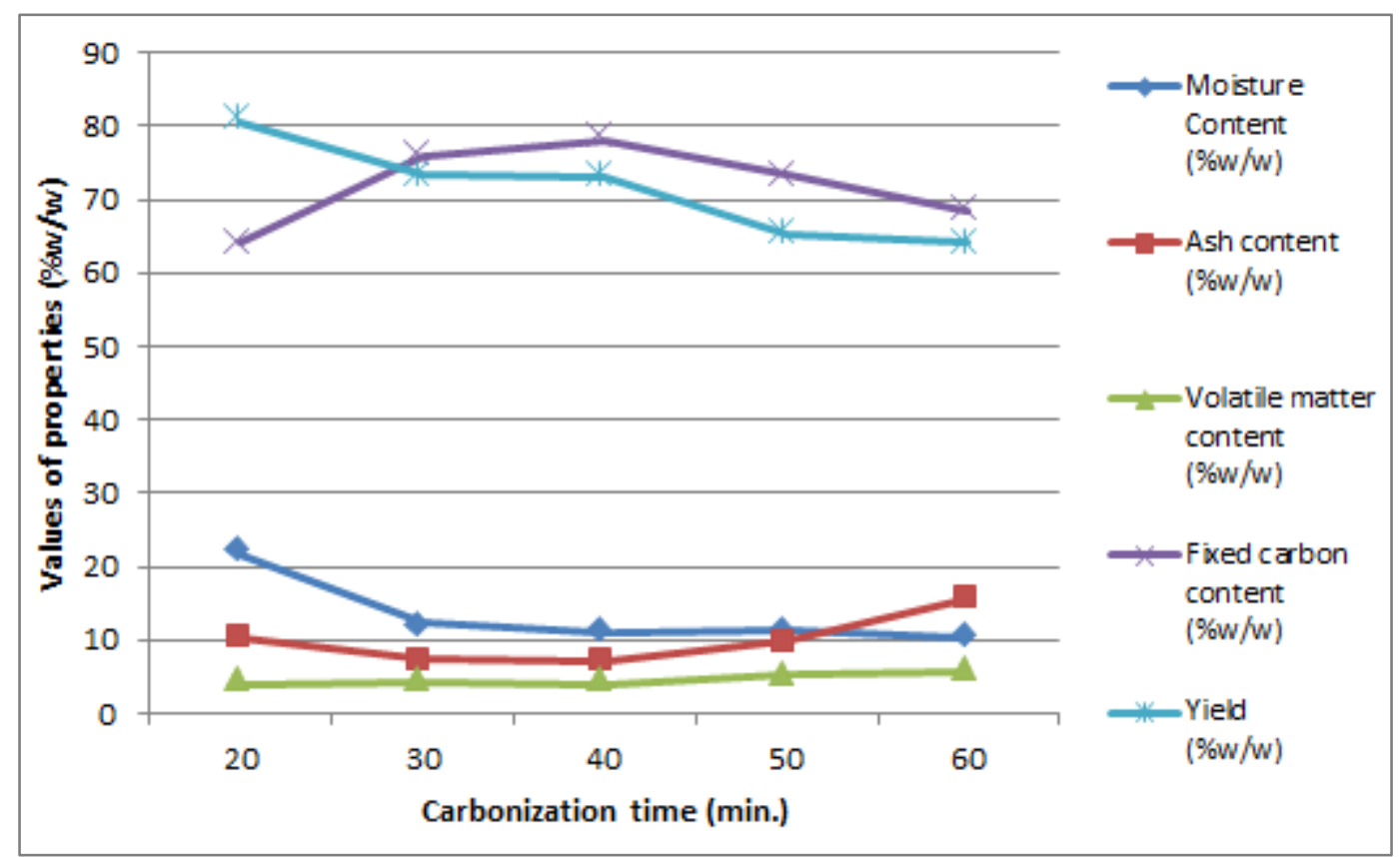

Figure 3. Effect of Carbonization Time on the Physico-chemical Properties of Corn Husk Activated Carbon

\subsubsection{Effect of Carbonization Time on Physico-chemical} Properties of Activated Carbon

The optimum carbonization time for corn husk activated carbon in $20 \% \mathrm{ZnCl}_{2}$ solution followed by carbonizing at $250^{\circ} \mathrm{C}$ (Fig. 3) was $40 \mathrm{~min}$. The yield of activated carbon decreased at longer carbonization period because of the higher carbon burn off.

\subsection{Analysis of Processed Corn Husk Activated Carbon}

Activated carbon which was prepared in $20 \% \mathrm{ZnCl}_{2}$ solution at $250^{\circ} \mathrm{C}$ for $40 \mathrm{~min}$. carbonization period gave the desired properties, high fixed carbon content, and low ash content (Table 2). The activated carbon obtained from this optimum condition was brittle, bright in color and light weight and these were the best characteristics for activated carbon.

Table 2. Analysis of Processed Corn Husk Activated Carbon

\begin{tabular}{|c|c|c|}
\hline Properties & $\begin{array}{c}\text { Experimental } \\
\text { Values }\end{array}$ & $\begin{array}{c}\text { *Literature } \\
\text { Values }\end{array}$ \\
\hline Moisture content $(\% \mathrm{w} / \mathrm{w})$ & 10.83 & 16.67 \\
\hline Ash content $(\% \mathrm{w} / \mathrm{w})$ & 7.04 & 8.84 \\
\hline Volatile matter content $(\% \mathrm{w} / \mathrm{w})$ & 4.08 & - \\
\hline Fixed carbon content $(\% \mathrm{w} / \mathrm{w})$ & 78.05 & 81.7 \\
\hline
\end{tabular}

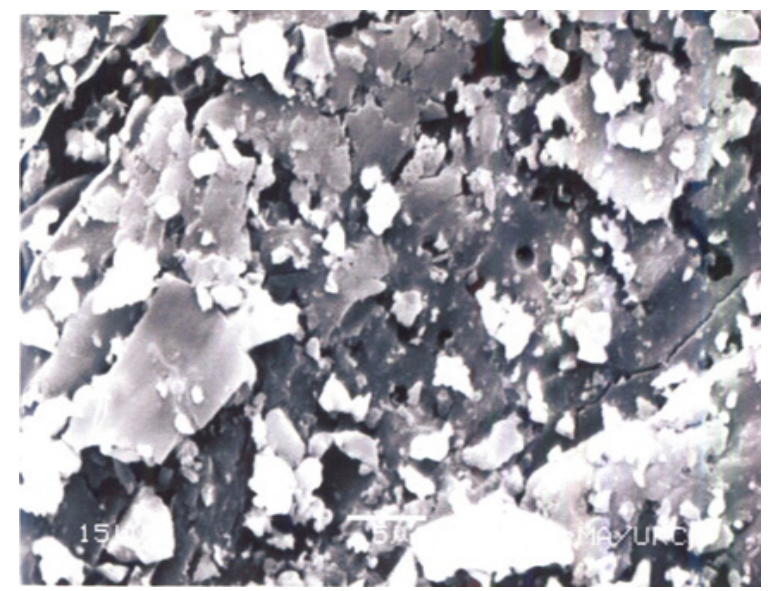

Figure 4. SEM Photograph of Processed Activated Carbon at 2700 magnification

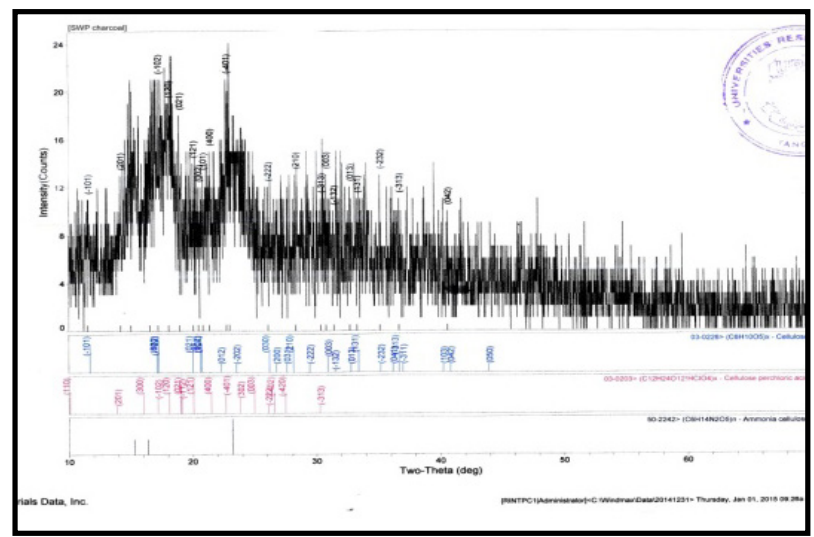

Figure 5. X-ray Diffractogram of Processed Activated Carbon 
Table 3. Characteristics of Processed Corn Husk Activated Carbon

\begin{tabular}{|c|c|c|}
\hline Characteristics & $\begin{array}{c}\text { Experimental } \\
\text { Values }\end{array}$ & $\begin{array}{c}\text { *Literature } \\
\text { Values }\end{array}$ \\
\hline $\mathrm{pH}$ & 6.6 & $6-8$ \\
\hline Surface area $\left(\mathrm{m}^{2} / \mathrm{g}\right)$ & 1360 & $800-1500$ \\
\hline Methylene blue number $(\mathrm{mg} / \mathrm{g})$ & 383 & 532 \\
\hline Iodine sorption capacity $(\%)$ & 71 & 80 \\
\hline Bulk density & 0.0417 & - \\
\hline
\end{tabular}

*Source: Okibe et al [10]

\subsection{Characteristics of Processed Activated Carbon}

Characteristics of processed activated carbon such as $\mathrm{pH}$, surface area, bulk density, methylene blue number and iodine sorption capacity are shown in Table 3 . The $\mathrm{pH}$ of activated carbon was 6.6. Most widely used commercial activated carbon has specific surface area of the order of $800-1500 \mathrm{~m}^{2} / \mathrm{g}[10,11]$. The surface area of corn husk activated carbon was $1360 \mathrm{~m}^{2} / \mathrm{g}$. Bulk density of processed activated carbon was $0.0417 \mathrm{~g} / \mathrm{cm}^{3}$. The bulk density is another important physical parameter especially when an activated carbon product is to be investigated for its fragility.

The prepared activated carbon had methylene blue number $383 \mathrm{mg} / \mathrm{g}$ and iodine sorption capacity is $71 \%$. The methylene blue number is a measurement of mesoporosity present in activated carbon and an indicator of ability of a carbon to adsorb high molecular weight substances like dye molecule. Iodine sorption capacity is related to the degree of micro and mesopores present in adsorbent. The results obtained for both parameters showed that the corn husk activated carbon has high micropores and mesopores. SEM photograph of prepared activated carbon was shown in Fig. 4. SEM photograph showed that wide variety of pores were present in activated carbon along with fibrous structure. The nature of the prepared activated carbon at optimum conditions and commercial activated carbon by the X-ray diffraction profiles was illustrated in Fig. 5 .The processed activated carbon with broad peaks and absence of sharp peak that observed predominantly amorphous structure, which is an advantageous property for well-defined porous adsorbents.

Table 4. Characteristics of Commercial Fish Sauce

\begin{tabular}{|c|c|c|}
\hline Characteristics & $\begin{array}{c}\text { Experimental } \\
\text { Values }\end{array}$ & $\begin{array}{c}\text { *Literature } \\
\text { Values }\end{array}$ \\
\hline $\mathrm{pH}$ & 5.58 & $5-6.5$ \\
\hline Sodium chloride content $(\% \mathrm{w} / \mathrm{w})$ & 31.5 & $20-30$ \\
\hline Protein content $(\% \mathrm{w} / \mathrm{w})$ & 6.51 & 10 \\
\hline Total nitrogen content $(\% \mathrm{w} / \mathrm{w})$ & 2.12 & - \\
\hline
\end{tabular}

*Standard for fish sauce (CODEX STAN 302-2011) [12]

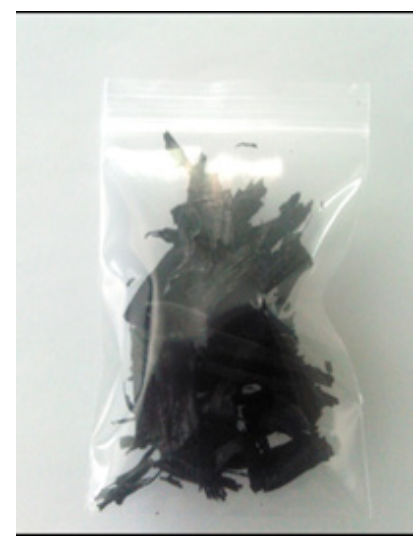

Figure 6. Corn Husk Activated Carbon

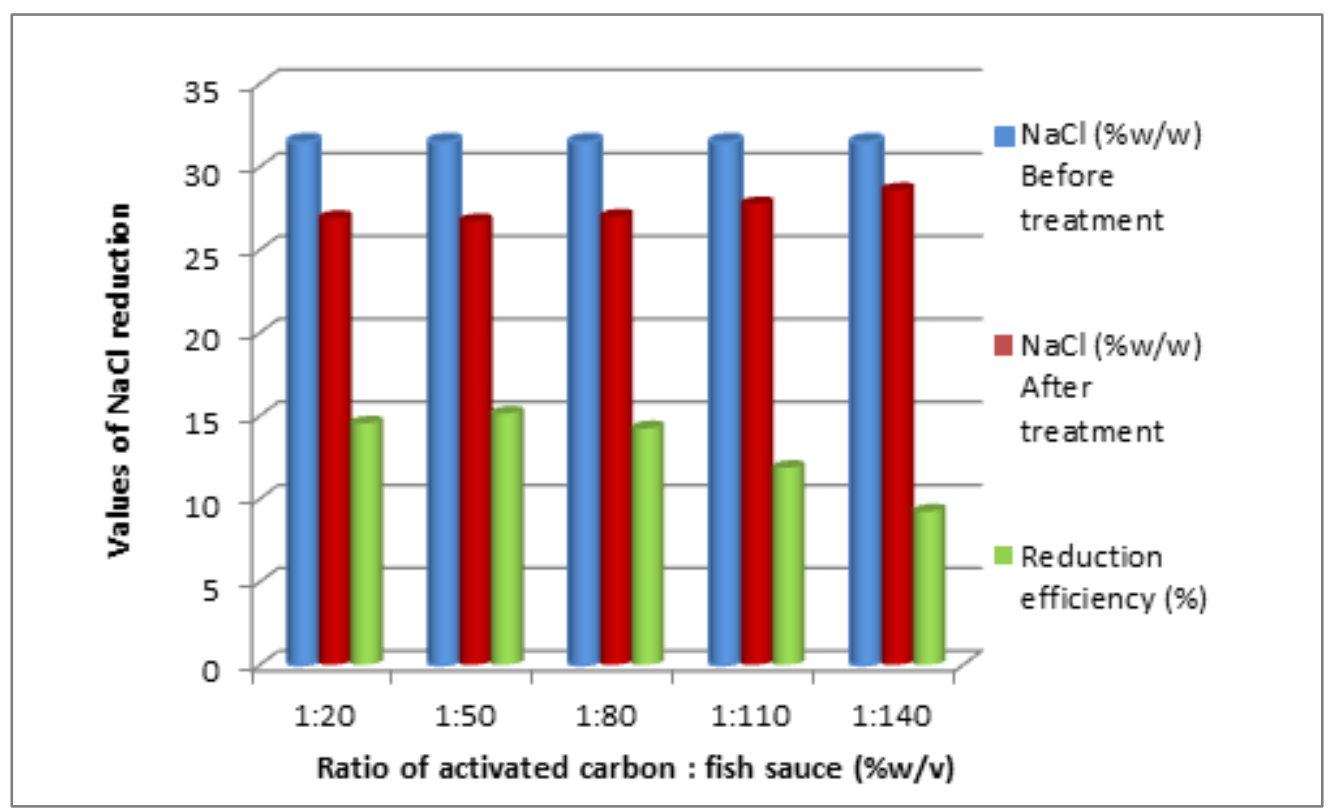

Figure 7. Effect of Corn Husk Activated Carbon to Fish Sauce Ratio on the Reduction of $\mathrm{NaCl}$ Content 


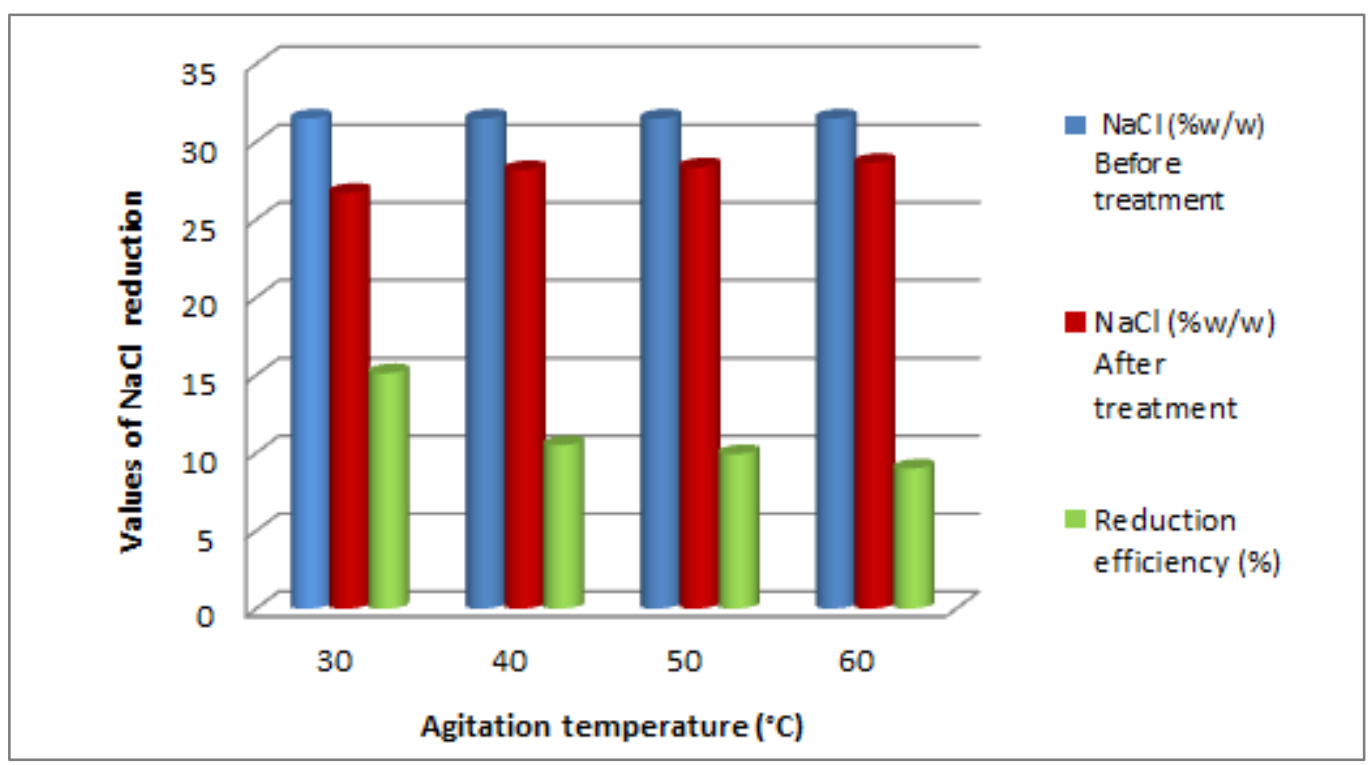

Figure 8. Effect of Agitation Temperature on the Reduction of $\mathrm{NaCl}$ Content in Fish Sauce

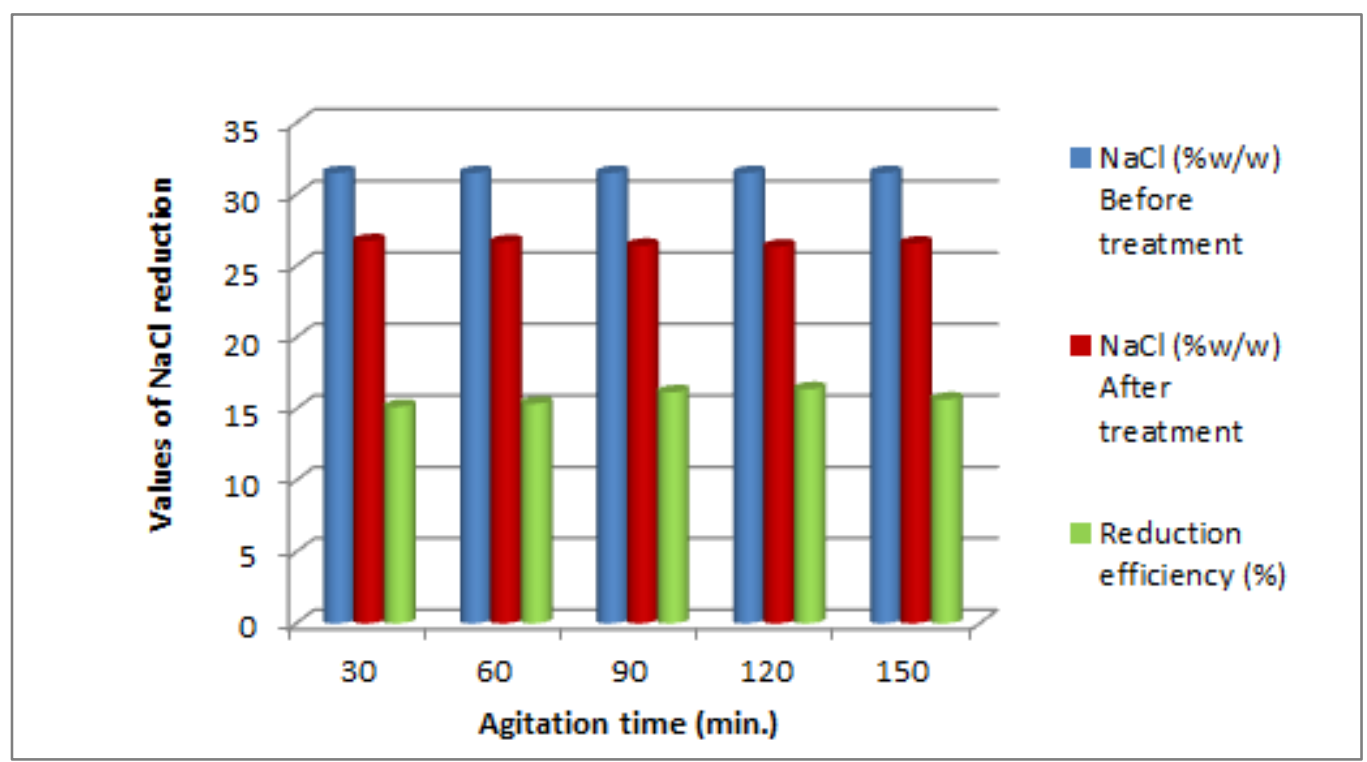

Figure 9. Effect of Agitation Time on the Reduction of $\mathrm{NaCl}$ Content in Fish Sauce

\subsection{Reduction of Sodium Chloride Content in Fish Sauce by Processed Activated Carbon:}

Characteristics of commercial fish sauce (product of Myanmar) were also investigated (Table 4.). Reduction of sodium chloride content in fish sauce treated with different ratios of activated carbon to fish sauce is shown in Fig. 7. It was found that the highest reduction efficiency of sodium chloride content (31.5 to $26.73(\% \mathrm{w} / \mathrm{w}))$ occurred at ratio of 1:50 activated carbon to fish sauce at room temperature $\left(30^{\circ} \mathrm{C}\right)$ with agitation $(200 \mathrm{rpm})$ for $1 \mathrm{hr}$. To determine the effect of temperature on the reduction efficiency of sodium chloride content in fish sauce, the appropriate ratio of activated carbon to fish sauce was further treated at higher temperature and results were shown in Fig. 8. It was found that the reduction efficiency decreased as the temperature was increased. And then, the effect of agitation time for reduction of sodium chloride in fish sauce was investigated. The appropriate ratio of activated carbon to fish sauce was again used for reduction at longer agitation time and data are presented in Fig. 9. The highest reduction efficiency of sodium chloride content was found at room temperature with agitation (200 rpm) for $120 \mathrm{~min}$.

\section{Conclusions}

The production of activated carbon from agricultural by-product has potential economic and reducing 
environmental impacts. It converts low-value agricultural waste to useful, high quality adsorbents. The quality of activated carbon depends on the preparation conditions. Zinc chloride was effective activating agent for preparation of the activated carbon from corn husk. Due to porous structure, organic nature and large scale availability, this was ideal raw material for preparation of activated carbon. The odor and color of fish sauce were partially reduced and sodium chloride reduction efficiency $16.38 \%$ by corn husk activated carbon observed at room temperature for $120 \mathrm{~min}$. agitation time at $200 \mathrm{rpm}$ agitation rate.

\section{Acknowledgements}

I wish to acknowledge to my supervisor Dr. Khin Thet $\mathrm{Ni}$, Professor and Head (Retd), Industrial Chemistry Department, University of Yangon and co-supervisor Dr. Thwe Linn Ko, Professor, Industrial Chemistry Department, University of Mandalay, Myanmar, for their invaluable guidance, and kind advice throughout the research period.

\section{REFERENCES}

[1] Activated carbon, Online available from https:/en. wikipedia.org/wiki/Activated carbon

[2] Ahmadpour, A., Do, D.D. The preparation of active carbons from coal by chemical and physical activation. Carbon, 34, pp 471-479, 1996.

[3] R. Gottipati. Preparation and characterization of microporous activated carbon from biomass and its application in the removal of chromium (VI) from aqueous phase, Department of Chemical Engineering National Institute of Technology, Rourkela, Odisha, India, pp 2, 2012.

[4] El-Hendawy, A.A., Alexander, A.J., Andrews, R.J., Forrest, G. Effects of activation schemes on porous, surface and thermal properties of activated carbons prepared from cotton stalks. Journal of Analytical and Applied Pyrolysis, Vol. 82, 272-278, 2008.

[5] Corn, Online available from https://www.britannica.Com/plant/corn-plant

[6] Corn Husk, Online available from http://www.specialtyproduce.com/produce/Corn-Husk-473. php

[7] M. Ahmedna, M.M. Johns, S.J. Clarke, W.E. Marshall, and R.M. Rao. Potential of agricultural byproduct-based activated carbons for use in raw sugar decolourisation. J Sci. Food Agri. Vol.75, 117-124, 1997.

[8] Cerator, A. B., Lutenegger, A. J. Determination of surface area of fine grained soils by the ethylene glycol monoethyl Ether (EGME) method Geotechnical Testing Journal. Vol. 25. No. (3), pp 1-7, 2002.

[9] ASTM Standards. ASTM D 2330. Standard test method for determination of methylene blue number of activated carbon. ASTM, USA, 2000.

[10] Okibe F.G.; Gimba C.E.; Ajibola .V.O ,Ndukwe I.G. Preparation And Surface Characteristics Of Activated Carbon From Brachystegia eurycoma And Prosopis africana Seed Hulls, International Journal of Chem. Tech Research, Vol. 5, No 4, pp 1994-1995, 2013.

[11] Bansal., R.C., Donnet, J.B and Stoeckli, F., Active carbon, Marcel Dekker, Inc., New York, USA, pp 77, 1988.

[12] Standard for fish sauce Online available from CONDEX STAN 302-2011 https://www.sda.gov.cn

[13] O. Ioannidou, A. Zabaniotou. Agricultural residues as precursors for activated carbon production - A review. Renewable and Sustainable Energy Reviews 11, pp 1976, 2007 